A. Gritsenko

Doctor

South Ural State University Department of Road Transport

Russia

V. Shepelev

Ph. D

South Ural State University Department of Road Transport

Russia

\section{E. Zadorozhnaya}

Doctor

South Ural State University Department of Road Transport Russia

\section{K. Shubenkova \\ Ph. D \\ Kazan Federal University \\ Transport Systems Service Department}

Russia
Test Diagnostics of Engine Systems in Passenger Cars

One of the priority directions in the development of instrument diagnostics of car engines is test diagnostics. The main advantages of such testing are: significant coverage of the diagnosed engine systems; high informativeness and reliability of the diagnostic process with general simplification of the diagnostic process; reduction in the number of diagnostic parameters. In addition, one can achieve high automation of diagnostic process operations, adaptation of diagnostics interfaces and high intuitive level of functioning algorithms. The authors developed a diagnostic instrumental tool - a loader for gasoline engines (LGE-3), as well as a device for fixing the position of the throttle. The loader of the gasoline engine LGE-3 allows us to create any load and speed mode. Load on the cylinder is provided due to a complete shutdown of fuel in any cylinder and by disabling individual fuel cycles in the selected cylinder. The results of experimental studies on the example of electromagnetic injectors have shown a high efficiency of test diagnostics. The diagnostics modes at 25 and $70 \%$ degree of throttle valve opening are designed and recommended.

Keywords: engine, fuel supply system, diagnostics, load mode, speed.

\section{INTRODUCTION}

A large number of instrumentation for diagnosing petrol engine systems of cars is available on the market of automotive equipment [1, 2, 3]. Enlarged they can be divided into five categories: 1 . Scanners of diagnostic codes; 2. Testers-scanners; 3. Motor-testers. 4. Electronic oscilloscopes; 5. Instrument means for test diagnostics.

Scanners of diagnostic codes allow us to read, recognize and erase trouble codes (in case of elimination of the cause of failure). However, their disadvantage is not the whole range of fault coverage, but only a small part of it, which obeys the logical structure of the algorithm. Most of the failures of system elements and engine components remain out of reach [4-6]. Actually, this forces the developers of diagnostic equipment to search for new ways of uncovering the uncertainty of connections in the process of diagnosing and developing instrumentation $[7,8]$.

The next common category are testers-scanners that can provide, in addition to scanning the error codes, also visualization of the system parameters that determine the operation of the engine, down to the system variables that allow us to judge the operation of the control program algorithm. However, the tests basically boil down to making some element work outside the system, in an unusual mode or with an unusual load [5]. At the same time, most test scanners fix the multiplicity and uncertainty of the technical state of the elements and systems. Motor testers allow us to collect and display the parameters of the engine and its systems irrespective of the electronic control unit and to provide

Received: January 2019, Accepted: June 2019

Correspondence to: Ph.D Vladimir Shepelev

South Ural State University, Department of Automobile

Transport, Chelyabinsk, Russia

E-mail: shepelevvd@susu.ru

doi:10.5937/fmet2001046G

(C) Faculty of Mechanical Engineering, Belgrade. All rights reserved control over the output parameters of actuators not controlled by the electronic engine management system. In addition, the provision of these diagnostic tools with high-voltage sensors, sensors-cylinder markers, pressure sensors, etc. significantly expands the range of possibilities [9- 12]. However, the spectra of the given regimes and the variation of the parameters are critically small and do not allow us to uncover the uncertainties and ambiguities of the constraints.

Electronic oscilloscopes today are leading in terms of sales along with scanners. For example, oscilloscopes like Motodoc and Usb Autoscope III-IV are available in almost every automotive service. The advantages of oscilloscopes are their essential functionality. Multichannel and multi-bit capabilities allow us to view rapidly changing processes in the microsecond range. In addition, more and more equipment of cars with electronics and digital devices contribute to the development of these diagnostic tools $[13,14]$.

The last category is represented by instrumentation for test diagnostics. Partly the elements of the test diagnostics are presented in motor-testers. So the common tests - cylinder balance, acceleration, coasting, etc. - are also used nowadays, but their implementation is carried out according to the hierarchy of special diagnostic algorithms while providing a wide range of load regimes [15].

All the presented diagnostic tools have a different cost from 1000 to $1,000,000$ rubles, technical capabilities and most importantly the coverage of the engine systems in the diagnostics, the parameters of accuracy and reliability $[15,16]$. In practice, the services combine various options for instrumentation, and sometimes different brands of vehicles require their own specific diagnostic tools [15-17].

Thus, the analysis of the above-mentioned equipment suggests several tasks in the development of diagnostic tools: 
1. A significant reduction in the cost of diagnostic tools and their quick payback.

2. An increase in the coverage of the diagnosed engine systems, the informativeness and reliability of the diagnostic process with the overall simplification of the diagnostic process and a reduction in the number of diagnostic parameters.

3. Automation of most operations in the diagnostic process, adaptation of diagnostics interfaces and high intuitive level of functioning algorithms, reduction of the laboriousness of the diagnostic process.

4. Universality and ergonomics of diagnostic tools.

The set tasks served as the basis for the development of the instrument diagnostics - the loader of gasoline engines LGE-3 and the device for ensuring the stepless loading of the engine cylinders [18]. In addition, more research was needed to develop methodology and software, a convenient management interface, practical development of diagnostic tests, technology and a diagnostic algorithm [15].

An important problem in the application of the test method of diagnostics is the complexity of providing load regimes. For this, it is necessary to develop a special device that steplessly sets the load and is controlled by a general diagnostic program. To develop such a device, we analyzed the possible options for its implementation. Thus, we took into consideration the following: an electric pedal, adjustable traction, rod and a pneumatic leg. However, along with the universality and simplicity of their manufacture and application, there are serious shortcomings that exclude their usage: a large inertia of operation, the necessity to keep a diagnostician or an additional worker, two end points possible. So we have made a device for fixing the throttle position (Figure 1).

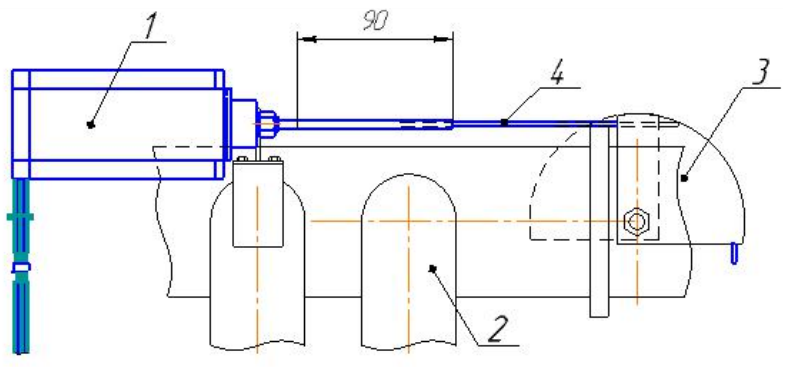

Figure 1. Device for fixing the position of the throttle: 1 stepper motor; 2 - inlet collector of the engine; 3 - throttle valve; 4 - draft

The device shown in Figure 1 can provide any angle of throttle position with high accuracy. And it is controlled from the interface of the working diagnostic program.

In the first stage, before the process of diagnosing the engine systems, the device is fixed to the intake manifold of the engine 2 . In the second stage, the device is adjusted by setting the zero and maximum opening of the throttle valve 3 by the thrust 4 . And also the free path of the device 4 is eliminated. After that the device is ready for operation.

\section{THEORETICAL RESEARCH}

We shall calculate the necessary parameters of the device for fixing the throttle position. The main element of the device is the stepper motor 1 (Figure 1) and the solenoid moving the throttle valve 3 . The number of the design parameters of the device includes the diameter of the winding wire. The active resistance of the solenoid and, consequently, the current in the winding at a given supply voltage depends on the diameter of the winding wire. In this case, it is necessary to achieve the required current density in the winding (for the selected SM in the given mode of re-intermittent switching, the design allowable current density in the winding is $7.3 \mathrm{~A} / \mathrm{mm}^{2}$ ) [18].

The number of turns of $\mathrm{N}$ wire of diameter $\mathrm{D}$ is determined by the area of the winding window $S$ of the solenoid and the packing factor $\lambda$ :

$$
N=\frac{4 \cdot S \cdot \lambda}{\pi \cdot D^{2}}
$$

where: $N$ is number of winding turns; $S$ is area of winding window, $\mathrm{m}^{2} ; \lambda$ is packing factor; $D$ is diameter of the winding wire, $\mathrm{m}$.

Then the resistance of the solenoid $R$ can be calculated as follows:

$$
R=\rho \frac{4 \cdot L_{A V} \cdot N}{\pi \cdot D^{2}}=\rho \cdot \lambda \cdot \frac{16 \cdot L_{A V} \cdot S}{\pi^{2} \cdot D^{4}},
$$

where: $L_{A V}$ is average length of one turn, $\mathrm{m}, \rho$ is electrical resistance of the winding wire, $\mathrm{Ohm} \cdot \mathrm{m}$.

The current $I$ flowing in the winding by the resistance $R$ under the action of the voltage $U$ is determined by Ohm's law:

$$
I=U / R
$$

The current density $j$ in the winding:

$$
j=\lambda \frac{4 \cdot I}{\pi \cdot D^{2}}=\frac{\pi \cdot D^{2} \cdot U}{4 \cdot \rho \cdot S \cdot L_{A V}} .
$$

From here, the diameter of the winding wire can be found:

$$
D=\sqrt{\frac{\rho \cdot S \cdot L_{A V} \cdot j}{\pi \cdot U}} .
$$

For a cylindrical solenoid, the average length of one turn is calculated by the formula:

$$
L_{A V}=\pi \cdot\left(R_{1}+R_{2}\right),
$$

where: $R_{1}$ is radius of the hole, $\mathrm{m} ; R_{2}$ is outer radius of the solenoid, $\mathrm{m}$.

The winding window area:

$$
L_{A V}=\pi \cdot\left(R_{1}+R_{2}\right) .
$$

where $H$ is winding length, $\mathrm{m}$.

The solenoid with parameters is chosen as the object of study: $U$ is $12 \mathrm{~V}, j$ is $7300000 \mathrm{~A} / \mathrm{m}^{2}, R_{2}$ is $0.09 \mathrm{~m}, R_{1}$ is $0.04 \mathrm{~m}, \rho$ is $1.67 \cdot 10^{-8} \mathrm{Ohm} \cdot \mathrm{m}$ (copper wire), $\lambda$ is $1, H$ is $0.05 \mathrm{~m}$.

$$
\begin{aligned}
& L_{A V}=3.14 \cdot(0.04+0.09)=0.408, \mathrm{~m}, \\
& S=0.05 \cdot(0.09-0.04)=0.0025 \mathrm{~m}^{2}, \\
& D=\sqrt{\frac{1.67 \cdot 10^{-8} \cdot 0.0025 \cdot 0.408 \cdot 7300000}{3.14 \cdot 12}} \approx 0.002, \mathrm{~m},
\end{aligned}
$$




$$
\begin{aligned}
& R=1.67 \cdot 10^{-8} \cdot 1 \cdot \frac{16 \cdot 0.408 \cdot 0,0025}{3.14^{2} \cdot 0.002^{4}}=1.72 \mathrm{Ohm} \\
& I=12 / 1.72 \approx 7 \mathrm{~A}, N=\frac{4 \cdot 0.0025 \cdot 1}{3.14 \cdot 0.002^{2}}=796 \mathrm{pc}
\end{aligned}
$$

Based on the results of the calculation, we select the stepper motor SM 57HS112-4004. In practice, the device showed a high speed and accuracy of setting the throttle angle.

\section{RESEARCH METHODOLOGY}

For carrying out experiments the research complex has been developed. It included a motor unit based on the engine ZMZ-406.10. The engine was a gasoline with 4 cylinders and 16 valves. The order of the cylinders was 1-3-4-2. The engine was equipped with a microprocessor control system.

The choice of the engine ZMZ - 406.10 as an object of research was based on the following features:

- it is very common on light-duty trucks;

- it is most adapted for diagnosing;

- the scheme of simultaneous fuel supply by injectors is used in the power supply system; this consists of a single injection of a portion of the fuel at the time of opening the intake valve;

- mounting the engine on the frame of the research stand is very simple.

The engine was installed on a research stand, which is a swinging frame. A number of elements are fastened to the frame of the research stand: a radiator, an electric fan, an electric fuel pump, a gas tank, etc. Exhaust ventilation is provided to remove exhaust gases. The research facility is equipped with a standard engine operation control system with a control panel, which includes an electronic engine control unit connected to sensors and executive mechanisms of the engine, an ignition lock, a fuse box, a relay and a standard instrument panel.

To provide load modes for fuel system studies, we developed a LGE-3 gasoline engine loader [15, 18], which allows us to create any load and speed mode for work processes in the cylinder under study. Load on the cylinder is provided due to a complete shutdown of fuel in any cylinder and by disabling individual fuel cycles in the selected cylinder. To control the operation of the injectors, in order to provide diagnostic modes, the injector switch is turned on between the connectors of the wires connected to the injectors and the injectors themselves.

The device - the electromagnetic injector switch - is intended for complex and element-by-element diagnostics of the mechanisms and systems of the internal combustion engine of Volga GAZ-3110 cars equipped with an electronic control unit (Mikas 7.1 and Mikas 5.4). The instrument kit includes: 1. The instrument is the electromagnetic injector switch; 2. Computer diagnostic program; 3 . Power cord. Technical specifications are presented in Table 1.

The device (injector switch) allows:

1. To estimate the relative and absolute maximum power of each cylinder separately and the engine as a whole in comparison of rotational speeds under test loads with the passport values for this type of engine.

2. To determine the uneven operation of the cylinders in various engine operating modes.

3. To remove the external high-speed characteristic of the engine for the purpose of an assessment of correctness of functioning of its tested systems and mechanisms.

4. To evaluate the performance of the following systems and mechanisms of the engine: power supply system; ignition systems; cylinder-piston group; gas distribution mechanism, sensors.

5. To identify the following engine problems:

- Places of air leaks in the intake collector;

- Violations of the tightness of the combustion chamber (cracks in the cylinder liner, burnout of the head gasket, valve leaks, gas passage through the rings);

- Uneven distribution of the fuel-air mixture in the cylinders;

- Violation of insulation of spark plugs and ignition coils, connecting low-voltage and high-voltage wires;

- Emergency wear of the cylinder-piston group, gas distribution mechanism, crank mechanism;

- Contamination of the filter element of the air filter;

- The quality of the fuel-air mixture;

- Breakage of the electrical circuits of the injectors and the electric fuel pump;

- Lack of control signals at the injectors;

- Efficiency of the injection system at idle and other modes;

- Operability of the reducing valve of the electric fuel pump, air flow sensor;

- Increased or decreased throughput capacity of the injectors and performance of the fuel pump;

- Ignition timing for maximum power in any mode.

Table 1. Technical specifications

\begin{tabular}{|l|c|}
\hline The name of the characteristics & Value \\
\hline Power supply (vehicle electrical system), V & $13.2 \ldots 16$ \\
\hline The number of cylinders of the tested engine & 4 \\
\hline $\begin{array}{l}\text { The number of completely disabled in any } \\
\text { combination of cylinders }\end{array}$ & $0 \ldots 4$ \\
\hline $\begin{array}{l}\text { The number of partially disconnected } \\
\text { cylinders }\end{array}$ & 4 \\
\hline $\begin{array}{l}\text { The degree of partial shutdown of the } \\
\text { cylinder,\% }\end{array}$ & $0 \ldots 100$ \\
\hline Disable partial shutdown, $\%$ & 10 \\
\hline
\end{tabular}

The injector switch allows us to control the operation of the electromagnetic injectors: turn off the injectors completely of the cylinders that are not involved in the diagnostics and turn off the injector operation for a specified number of cycles in the diagnosed cylinder, and also change the cyclic flow rate of the selected injector.

The working interface of the diagnostic program for diagnosing the engine by the LGE-3 petrol engine loader is shown in Figure 2.

Figure 2 in the working window of the interface displays the diagnostic information: revolutions - engine speed $3320 \mathrm{~min}^{-1}$; temperature - coolant temperature 
$93^{\circ} \mathrm{C}$; throttle - percentage of throttle opening $98 \%$; correction AIA - correction of an angle of ignition advancing of 10 degrees; position of the AAC - position of the additional air controller 99 steps; fuel consumption - real fuel consumption of $23.2 \mathrm{l} / \mathrm{h}$ and other parameters.

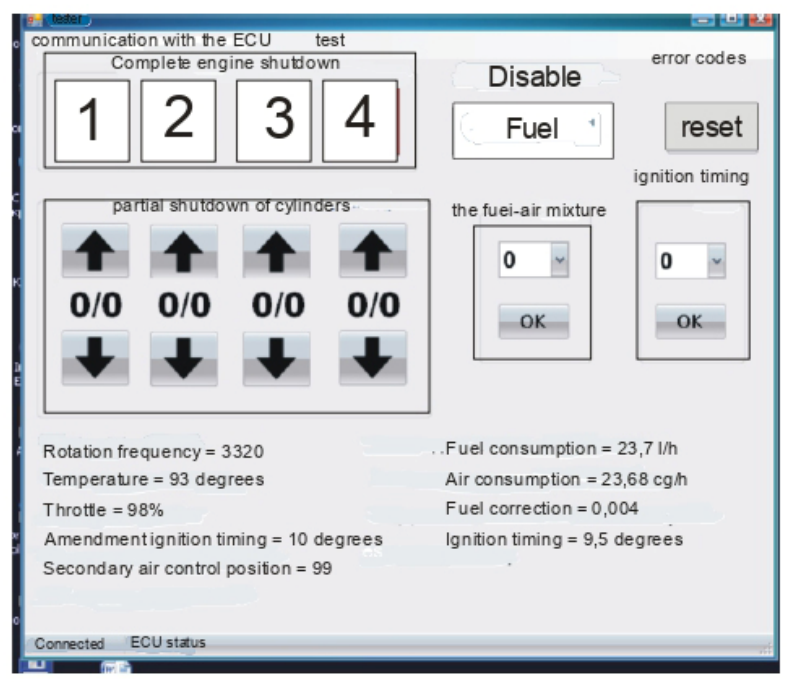

Figure 2. Operating interface of the diagnostic program for diagnosing the engine with a diesel engine loader LGE-3

To carry out the experiment, the injectors with the maximum allowable throughput needed to be prepared. Additionally technically sound - the standard injector was prepared. Additionally, a reference injector was prepared. It was a new injector, the parameters of which corresponded to the regulatory and technical documentation of the manufacturer BOSCH 0280150711, with a capacity of $192, \mathrm{~cm} 3 / \mathrm{min}$. The output parameters of the injectors were checked on the "Forsazh" diagnostic stand. This stand can operate in the mode of testing the injectors for throughput at various modes of imitation of the number of turnovers of the engine crankshaft: 800 , $1500,3000,6000 \mathrm{~min}^{-1}$ and constantly open injectors. At the same time, up to six tested injectors can be installed on the stand.

To prepare a injector with a reduced capacity, we reduced the flow area of the built-in injector filter by selecting gaskets with calibrated holes of $0.5 \ldots 3.0 \mathrm{~mm}$. Next, the standard injector and injectors with built-in calibrated gaskets were installed on the pouring stand. Injectors spilled on all modes of testing. A special cylinder with a measuring scale was installed on the stand. This cylinder was used to compare the volume of fuel from the injectors of the test group with the reference injector.

Reducing the throughput of the injector was achieved by installing gaskets with calibrated holes in the injector filter by $-3 \%$ and $-6 \%$ of the selected reference injector. Changes in throughput by $-6 \%$ corresponds to the marginal change in throughput of the injector from a technically serviceable; a decrease of $3 \%$ was chosen based on the fact that the plant manufactures injectors with a spread of throughput of no more than $\pm 2 \%$.

To prepare injectors with increased throughput, the injector throat was increased. For this, the exit channel behind the locking needle was unfolded using a set of drills. Next, the reference injector and injectors with enlarged flow areas of the injector were mounted on the stand. Injectors were spilled on all modes of testing. The fuel consumption for the injectors of the test group was compared with the reference injector and sampled. We sought to increase the throughput of the injector by 3 and $6 \%$ of the reference. The change in injector throughput is presented in Table 2.

Table 2. The results of the spilled injectors in the mode of continuous opening of the injectors

\begin{tabular}{|c|c|c|}
\hline \multirow{2}{*}{ The injector throughput } & \multicolumn{2}{|c|}{ Value } \\
\cline { 2 - 3 } & $\%$ & $\mathrm{ml}$ \\
\hline Extremely enlarged & 6 & 74 \\
\hline Increased & 3 & 72 \\
\hline Reference & 0 & 70 \\
\hline Reduced & -3 & 68 \\
\hline Extremely reduced & -6 & 66 \\
\hline
\end{tabular}

Injector throughput:

- the injector capacity for the first cylinder always corresponded to the reference value;

- the throughput of the injector for the third cylinder corresponded to reduced by $-6 \%$ from the reference throughput, and for the fourth cylinder was increased by $+6 \%$.

With this assembly of the engine to go to any point of the plan-matrix, you only need to go to the corresponding cylinder.

For the experiment, an electromagnetic injector switch and a diagnostic complex with MT-4 software were connected to a research stand. On the main menu of the MT-4 program, we selected the item parameters required for the study: engine temperature; throttle position; engine speed.

For the test cylinder, the load mode was created due to the sequential shutdown of other cylinders (except the test one). The engine crankshaft speed was set by the degree of throttle opening. For the first mode, the engine crankshaft speed was $2500 \mathrm{~min}^{-1}$, which approximately corresponded to $25 \%$ of throttle opening.

For the second mode, the load was created higher due to partial shutdown of the test cylinder by $20 \%$. The engine crankshaft speed was 3000 min-1, which roughly corresponded to $70 \%$ of the throttle opening.

According to the selected diagnostic modes, it was necessary to establish the quality of the fuel assembly. Therefore, the device was transferred to the fuel assembly correction mode. We achieved the maximum rotational speed of the engine crankshaft by pressing the "+" button (assembly enrichment) or “-” (assembly impoverishment).

After the diagnostic mode was set, we switched on the first cylinder (the test cylinder was turned off), so that the engine always worked on only one cylinder. We compared the change in crankshaft speed between the test cylinder and the first one. This operation was repeated similarly for the remaining engine cylinders.

\section{RESULTS OF EXPERIMENTAL STUDIES}

Experimental studies were carried out using the diagnostic tools described in the methodology. Dependen- 
cies of the engine crankshaft speed on the change in the capacity of the electromagnetic injectors $[15,16,20]$ are obtained at the throttle opening modes of 25 and $70 \%$.

At the initial stage of the experimental studies, adjustments were made for the engine ZMZ 4062 in three different modes of engine operation when the throttle was opened 25, 50, $75 \%$ (Figure 3).

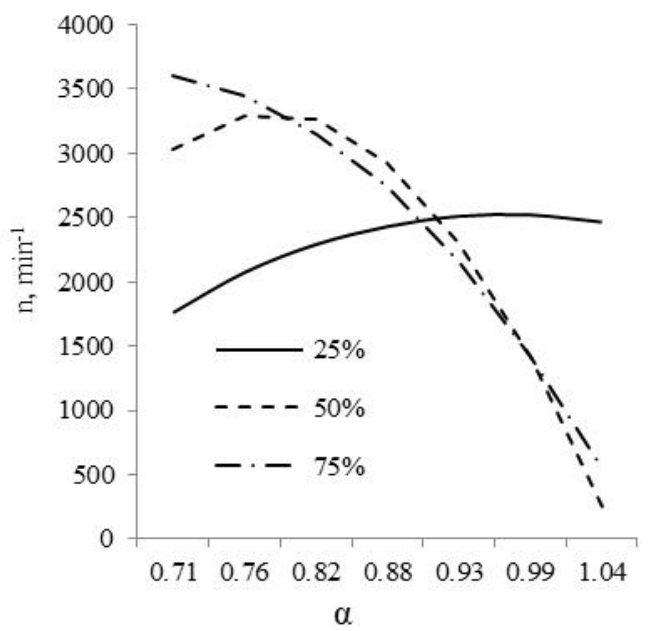

Figure 3. Dependency of the change in engine speed of the engine crankshaft $n$, min $^{-1}$ on the coefficient of excess air for various degrees of throttle opening

The adjustment characteristics shown in Figure 3 are approximated by the following equation:

$$
\begin{aligned}
& n=\left(45.984 \cdot z^{2}-4.817 \cdot 10^{3} \cdot z+8.096 \cdot 10^{4}\right) \cdot \alpha^{2}+ \\
& +\left(-72.584 \cdot z^{2}+7.425 \cdot 10^{3} \cdot z-1.195 \cdot 10^{5}\right) \cdot \alpha+ \\
& +27.754 \cdot z^{2}-2.748 \cdot 10^{3} \cdot z+4.383 \cdot 10^{4}
\end{aligned}
$$

where $\alpha$ - coefficient of excess air; $z$ - degree of throttle opening of the engine, $\%$.

To determine the most sensitive diagnostic regime, we differentiate equation (8) by $\alpha$. As a result:

$$
\begin{aligned}
& \varepsilon=2 \cdot \alpha \cdot\left(45.984 \cdot z^{2}-4.817 \cdot 10^{3} \cdot z+8.096 \cdot 10^{4}\right)- \\
& -72.584 \cdot z^{2}+7.425 \cdot 10^{3} \cdot z-1.195 \cdot 10^{5},
\end{aligned}
$$

Substituting different values $\alpha$ and $z$ in the equation (9) we obtain the dependency (Figure 4).

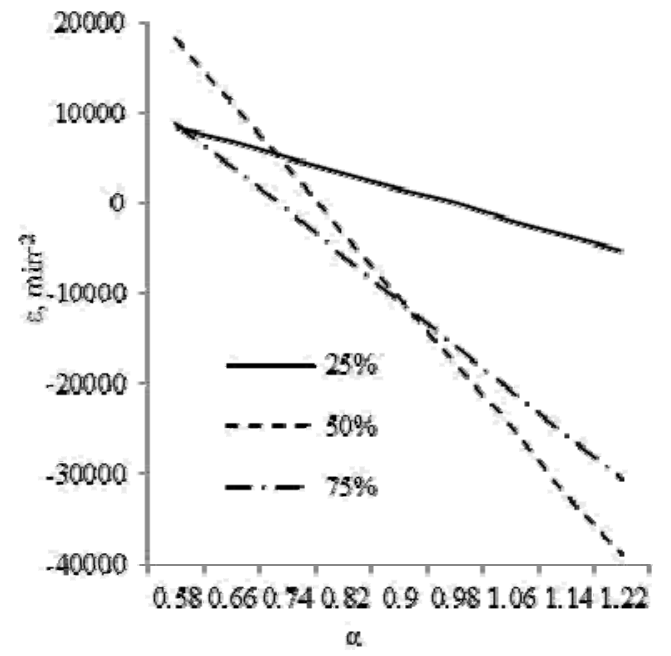

Figure 4. Dependency , $\mathrm{min}^{-2}$ on the excess air factor with 3 diagnostic modes: 1 - 25\%, 2 - 50\%, 3 - 75\%
From graphs 3 and 4 it follows that the electromagnetic injectors should at least be diagnosed in two modes: for small injection times (at $25 \%$ of the throttle opening) and close to the maximum (at 70-80\% opening of the throttle). At small fuel supply durations, the opening time and the closing time of the injector needle have a significant effect on the fuel supply. For longer durations: the duration of the time the injector is constantly opened. For the main part of the experimental studies, two modes were chosen: $25 \%$ of the throttle opening (small fuel feed) and $70 \%$ - with large fuel flows. Diagnostic electromagnetic jets were divided into 5 levels by the throughput in 3\% increments $(+6 \%$, $+3 \%, 0 \%,-3 \%,-6 \%$ ), because the permissible accuracy of their manufacturing is $2 \%$.

Analysis of the results allows us to draw the following conclusions, which are necessary for the selection of diagnostic modes.

1. The greatest change in the frequency of rotation of the crankshaft of the internal combustion engine is observed when the throttle is opened by $50 \%$, depending on the coefficient of excess air.

2. The poorer the fuel assembly, the greater the change in the rotational speed of the engine crankshaft is the variation $\alpha$.

3. The smallest sensitivity of the rotational speed of the crankshaft of the internal combustion engine to a change in the quality of the fuel assembly at the load of $25 \%$ corresponds to $\alpha=0.96$; with the load of $50 \%$, the value of $\alpha$ is 0.78 ; with the load of $75 \%$, the value of $\alpha$ decreases to 0.67 .

4. At the points of least sensitivity, the rotational speed of the engine crankshaft is maximum, with the load of $25 \%$, the rotational speed of the engine crankshaft $\mathrm{n}$ is $2500 \mathrm{~min}-1$; with the load of $50 \% \mathrm{n}$ is $3300 \mathrm{~min}-1$; with the load of $75 \% \mathrm{n}$ is $3600 \mathrm{~min}-1$.

The smallest load during stable operation of the internal combustion engine on one electromagnetic injector is $25 \%$ of the opening of the throttle. Therefore, it should be the diagnostic mode for assessing changes in throughput. To determine the change in throughput of the electromagnetic injector when the needle is fully raised, it is necessary to select the diagnostics mode corresponding to $70 \%$ of the throttle opening for the following reasons.

1. It is far enough away from the throttle position, at which the full power indication is turned on, at which the power supply system provides an enriched fuel assembly.

2. The pulse duration in this mode is maximum when the internal combustion engine is operating in optimal mixtures.

3. The change speed of the engine speed in this mode is slightly inferior to the operation mode of the engine at $50 \%$ throttle opening.

As a result of the experiment, we obtained the dependency of the change in engine speed of the crankshaft $n, \min ^{-1}$ on the capacity of the injector $\mu f, \%$ at the throttle opening modes $25 \%$ and $70 \%$ (Figure 5).

We conducted an assessment of the sensitivity, stability and informativeness of the diagnostic parameters of the electromagnetic injector.

The standard deviation of the theoretical dependence of the engine speed on the dependence obtained 
experimentally on the throttle opening mode by $25 \%$ was $2 \%$, which corresponds to the accuracy of measuring the engine speed of the injector switch.

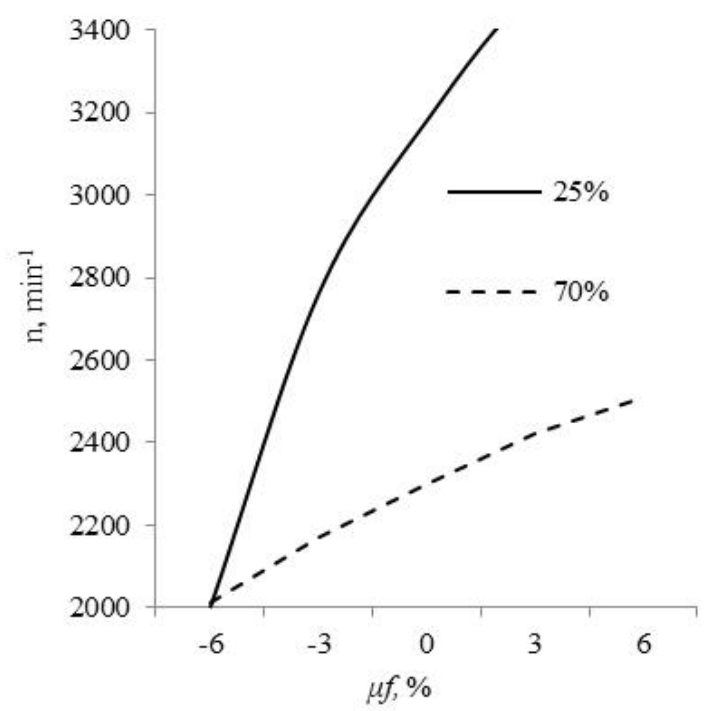

Figure 5. Dependency of the change in engine speed of the crankshaft $n, \min ^{-1}$ on the capacity of the injector $f, \%$ at the throttle opening modes

The sensitivity of the diagnostic parameter for extremely increased injector throughput $K$ is $35 \mathrm{~min}^{-1}$. The sensitivity of the diagnostic parameter for extremely reduced injector throughput $K$ is $36 \mathrm{~min}^{-1}$. The sensitivity of the diagnostic parameter for injectors with increased and decreased throughput is the same. A change in throughput of $1 \%$ causes a change in the engine speed of $35,36 \mathrm{~min}^{-1}$. With the measurement resolution of $40 \mathrm{~min}^{-1}$, the throughput can be monitored within $2 \%$, which is quite enough to determine the limit values of the injector throughput.

Stability is characterized by the standard deviation of the diagnostic parameter. The standard deviation is:

- for the throughput capacity of the technically serviceable injector $\sigma=38.7 \mathrm{~min}^{-1}$; $\min ^{-1}$;

- for extremely increased injector capacity $\sigma=20$ $\min ^{-1}$.

- for extremely reduced injector capacity $\sigma=25.2$

The stability of the diagnostic parameter does not exceed the discreteness of measuring the speed of rotation of the engine crankshaft.

The informativeness of the diagnostic parameter of the throughput of the technically serviceable injector relative to the injector with the increased throughput $I$ is 3.4. The informativeness of the diagnostic parameter of the throughput of the technically serviceable injector relative to the injector with the reduced throughput $I$ is 3.5. The informativeness of the diagnostic bandwidth parameter exceeds the value of $3 \sigma$, this indicates the absence of errors of the first and second type. The studied parameter has all the qualities imposed on the diagnostic parameters and therefore can be selected as the diagnostic one.

The change in the engine speed on one operating cylinder can be selected as a diagnostic parameter, as it is very sensitive to changes in the throughput of electro- magnetic injectors. As a result of experimental studies, empirical dependencies were obtained as the main result: - for the mode of small fuel flows (25\% opening of the throttle valve)

$$
n=-1.825 \cdot \mu f^{2}+38.333 \cdot \mu f+2.343 \cdot 10^{3} ;
$$

- for the maximum feed rate $(70 \%$ opening of the throttle valve)

$$
n=-8.81 \cdot \mu f^{2}+125.5 \cdot \mu f+3.098 \cdot 10^{3} .
$$

\section{CONCLUSION}

Using these dependencies in the operation of automobile engines, one can with an accuracy not less than $95 \%$ distinguish the faults in the mechanical, hydraulic and electrical parts of the electromagnetic injectors. A change in the nozzle throughput of $1 \%$ causes a change in the engine speed from the reference engine by $100-$ $150 \mathrm{~min}^{-1}$, which can be determined with high accuracy with the help of the described diagnostic tool.

\section{ACKNOWLEDGMENT}

The work was supported by Act 211 Government of the Russian Federation, contract № 02.A03.21.

\section{REFERENCES}

[1] Klaasen, K.B.: Basis of Measurement. Electronic methods and instruments in measuring technology, (in Russian) Postmarket, Moscow, 2000.

[2] Gross, A.W.: Gas film lubrication, John Wiley and Sons, New York, 1992.

[3] Shumilin, A.D., Liandenburgsky, V.V., Kapunova, M.K., Ivakhin, V.V., Moiseev, I.S.: Expert system of the control of a technical condition of cars, Scientific review, No 4, pp. 85-89, 2016.

[4] Wołczyński, Z., Komorska, I., Borczuch, A.: Fault simulation of the sensors in gasoline engine control system, in: Proceedings of the IOP Conference Series: Materials Science and Engineering, 1314.09.2018, Cracow, Paper 022042.

[5] Franchek, M.A., Buehler, P.J., Makki, I.: Intake air path diagnostics for internal combustion engines, Journal of Dynamic Systems, Measurement and Control, Transactions of the ASME, Vol. 129, No.1, pp. 32-40, 2007.

[6] Snedkov, B.A., Udalov, L.V., Ovodova, O.N., Gorokhov, Yu.V., Snedkov, A.B.: Pulse-packet electron injector for the study of rarefied media, Instruments and Experimental Techniques, Vol. 33. No. 1, pp. 25-28, 1990.

[7] Vertey, M.L.: Substantiation of the method for accelerating the engine with forced injection of fuel and electric control of the fuel supply during the test diagnosis, (in Russian) Bulletin of the Altai State Agrarian University, No. 2 (124), pp. 112116, 2015.

[8] Belov, A.B., Gumelyov, V.Yu.: Electromagnetic nozzle with high voltage control, (in Russian) 
Modern scientific research and innovations, No. 10 (30), pp. 6, 2013.

[9] Hsu, P., Lin, K., Shen, L.: Diagnosis of multiple sensor and actuator failures in automotive engines, IEEE Transactions on Vehicular Technology, Vol. 44, No.4, pp. 779-789, 1995.

[10] Wenzel, T.A., Burnham, K.J., Blundell, M.V., Williams, R. A.: Kalman filter as a virtual sensor: Applied to automotive stability systems, Transactions of the Institute of Measurement \& Control, Vol. 29, No. 2, pp. 95-115, 2007.

[11] Petrović, V.S., Janković, S.P., Tomić, M.V., Jovanović, Z.S., Knežević, D.M.: The possibilities for measurement and characterization of diesel engine fine particles, A review. Thermal Science, Vol. 15, No. 4, pp. 915-938, 2011.

[12] Petrović, V., Bracanović, Z., Grozdanić, B., Petrović, S., Sazhin, S., Knežević, D.: The design of a full flow dilution tunnel with a critical flow venturi for the measurement of diesel engine particulate emission, FME Transactions, Vol. 43, No. 2, pp. 99-106, 2015.

[13] Komorska, I., Woczyski, Z., Borczuch, A.: Fault diagnostics in air intake system of combustion engine using virtual sensors, Diagnostyka, Vol. 19, No. 1, pp. 25-32, 2018.

[14] Nyberg, M.: Model-based diagnosis of an automotive engine using several types of fault models, IEEE Transactions on Control Systems Technology, Vol. 10, No. 5, pp. 679-689, 2002.

[15] Plaksin, A.M., Gritsenko, A.V., Glemba, K.V., Lukomsky, K.I., Shepelev, V.D.: Test methods for diagnosing systems of internal combustion engines of cars, (in Russian) South-Ural SAU, Chelyabinsk, 2016.

[16] Scattolini, R., Siviero, C., Mazzucco, M., Ricci, S., Poggio, L., Rossi, C.: Modeling and identification of an electromechanical internal combustion engine throttle body, Control Engineering Practice, Vol. 5. No. 9, pp. 1253-1259, 1997.

[17] Eriksson, L., Nielsen, L.: Ionization current interpretation for ignition control in internal combustion engines, Control Engineering Practice, Vol. 5. No. 8, pp. 1107-1113, 1997.

[18] Gritsenko, A.V., Bakaykin, D.D., Kukov, S.S.: Method for diagnosing the fuel supply system of an engine, (in Russian) Patent No. 2418190 RU F 02 M 65/00 №2009123798, Bulletin No. 13, 2011.

\section{ПОСТУПАК ДИЈАГНОСТИКЕ СТАЫА СИСТЕМА МОТОРА ПУТНИЧКИХ ВОЗИЛА}

\section{А. Грисенко, В. Шепелев, Е. Задорожнаја, К. Шубенкова}

Један од главних праваца развоја дијагностике инструмената мотора путничких возила јесте дијагностички тест. Његова предност је што покрива значајан део система мотора, пружа велики број информација, дијагностички процес је поуздан и поједностављен, број дијагностичких параметара је смањен. Поред тога, остварује се аутоматизација дијагностичког процеса, адаптација интерфејса за дијагностику и висок интуитивни ниво примењених алгоритама. Аутори су развили алат за дијагностику - бризгаљку за бензински мотор и уређај за фиксирање положаја лептира. Бризгаљка омогућава достизање сваког оптерећења и сваке брзине. Оптерећење цилиндра се постиже потпуним затварањем довода горива и спречавањем сваког појединачног циклуса сагоревања у цилиндру по избору. Експериментални резултати добијени помоћу електромагнетских бризгаљки су показали велику ефикасност дијагностичког поступка. Дијагностика са лептиром отвореним 25\% и $70 \%$ се препоручује и пројектује. 